University of Nebraska - Lincoln

DigitalCommons@University of Nebraska - Lincoln

$7-2002$

\title{
Public Attitudes and Knowledge of the Black-tailed Prairie Dog: A Common and Controversial Species
}

\author{
Donna Lybecker \\ Department of Political Science at Colorado State University in Fort Collins \\ Berton Lee Lamb \\ Policy Analysis and Science Assistance Program at the Midcontinent Ecological Science Center (MESC), \\ US Geological Survey, Fort Collins, Colorado \\ Phadrea Ponds \\ MESC
}

Follow this and additional works at: https://digitalcommons.unl.edu/usgsstaffpub

Part of the Earth Sciences Commons

Lybecker, Donna; Lamb, Berton Lee; and Ponds, Phadrea, "Public Attitudes and Knowledge of the Blacktailed Prairie Dog: A Common and Controversial Species" (2002). USGS Staff -- Published Research. 36. https://digitalcommons.unl.edu/usgsstaffpub/36

This Article is brought to you for free and open access by the US Geological Survey at DigitalCommons@University of Nebraska - Lincoln. It has been accepted for inclusion in USGS Staff -- Published Research by an authorized administrator of DigitalCommons@University of Nebraska - Lincoln. 


\section{Public Attitudes and Knowledge of the Black-tailed Prairie Dog: A Common and Controversial Species}

DONNA LYBECKER, BERTON LEE LAMB, AND PHADREA D. PONDS

B lack-tailed prairie dogs (Cynomys ludovicianus; hereafter, prairie dogs) are native to the short-grass prairie region of North America from Mexico to Canada (figure 1). According to government documents (64 Federal Register 57 at 14426-14427), before the 19th century expansion of the United States, prairie dogs inhabited millions of acres of the Great Plains and lived in huge colonies west of the Missouri River. Settlement of the Great Plains and the transformation of vast areas from native grassland to tilled farmland forever changed the prairie ecosystem and prairie dog habitat.

Over the course of the last century, the habitat range of the prairie dog shrank by nearly 99 percent (Dolan 1999, Kotliar et al. 1999). Among the causes of shrinkage is poisoning: Livestock operators began extensive poisoning of prairie dogs around 1880, and the federal government began subsidizing prairie dog poisoning in 1915, quickly making it an institutionalized practice for federal, state, tribal, and county governments (Dunlap 1988). Prairie dog numbers have been further reduced by disease (i.e., sylvatic plague [Yersinia pestis]; Barnes 1993), drought, urban sprawl, cultivation and grazing practices, and recreational shooting.

Because of the controversy over the status of the species, much of the recent research on prairie dogs explores the extent and nature of competition between prairie dogs and cattle for forage and the economic justifications for prairie dog control (O'Meilia et al. 1982, Collins et al. 1984, Uresk and Paulson 1989, Mulhern and Knowles 1995). There is also an ongoing scientific debate about whether prairie dogs are a keystone species and the extent to which they fulfill functions not duplicated by other species (Stapp 1998, Kotliar et al. 1999). Incomplete and emerging scientific understanding of prairie dogs and their relation to a changing ecosystem fuels not only these debates but also a public policy controversy (Gerhardt 2000). The outcome of this debate may guide policymaking for other widespread but threatened species.

Many researchers and environmentalists consider the management and conservation of prairie dogs to be vital not only for the survival of the prairie dogs but also for the effective conservation of a large number of other grassland species, including predators such as the black-footed ferret (Mustela nigripes), ferruginous hawk (Beuto regalis), and burrowing owl (Athene cunicularia) (Knopf 1993, Miller et al. 1996, Kotliar et al. 1999). The National Wildlife Federation, Predator Project, and Biodiversity Legal Foundation petitioned the federal government to acknowledge the declining numbers of prairie dogs and recognize their importance to the prairie ecosystem by determining that the black-tailed prairie dog is a threatened species (64 Federal Register 57 at 14425).

In 2000 the US Fish and Wildlife Service (FWS) found (under section 4[b] of the Endangered Species Act) that list-

Donna Lybecker (e-mail: dlybeck@lamar.colostate.edu) is a $\mathrm{PhD}$ candidate in the Department of Political Science at Colorado State University in Fort Collins. Her research interests include environmental policy and management in the western US and northern Mexico. Berton Lee Lamb is the director of the Policy Analysis and Science Assistance Program at the Midcontinent Ecological Science Center (MESC), US Geological Survey, Fort Collins, Colorado; he is past-president of the Western Social Science Association and has published more than 30 articles on natural resource policy and management. Phadrea $D$. Ponds is a wildlife biologist at MESC specializing in the human dimensions of wildlife management; her specialty is in measures of environmental quality of life. ( $) 2002$ American Institute of Biological Sciences. 


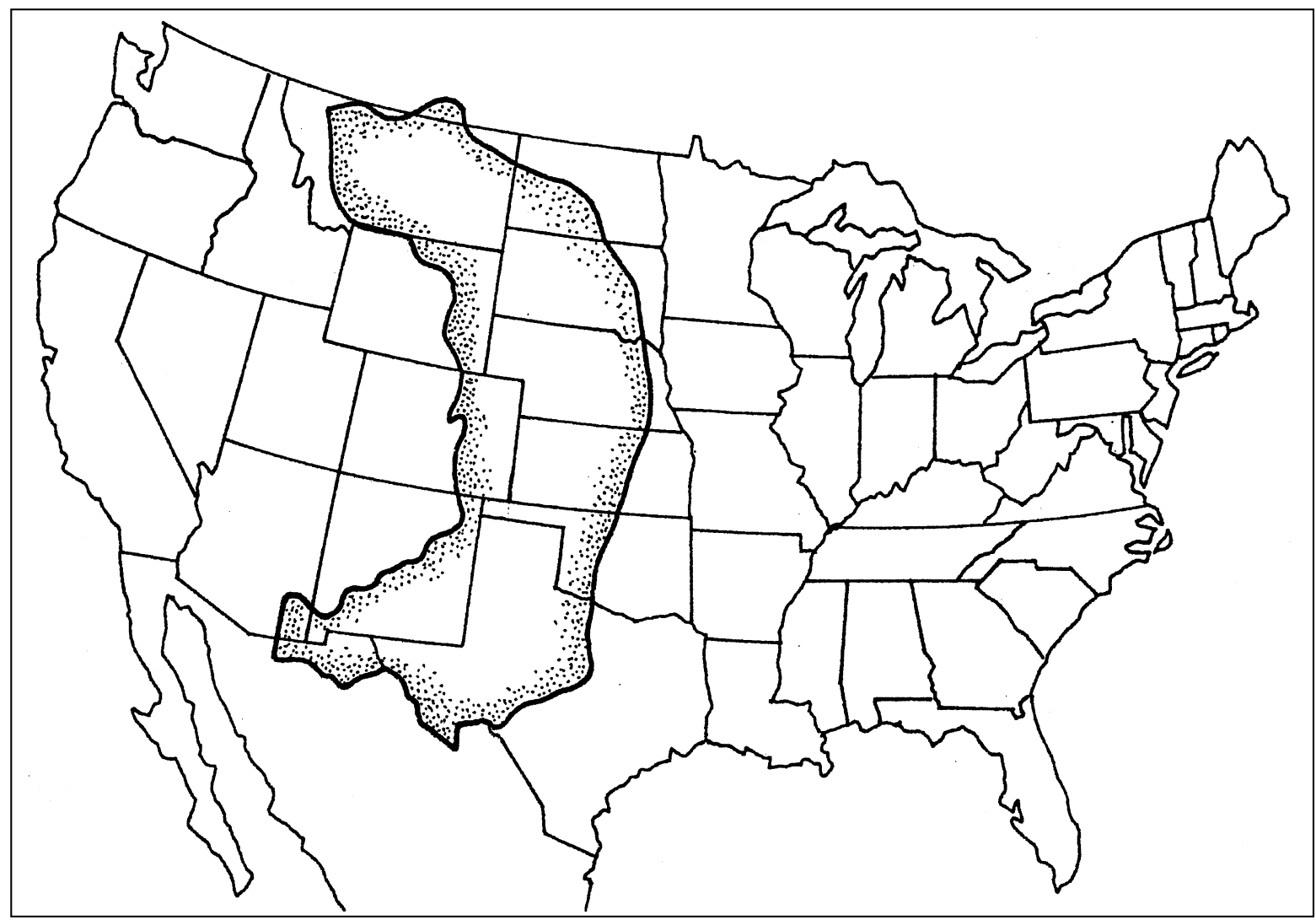

Figure 1. Geographic distribution of black-tailed prairie dogs' historic range in the United States.

ing the black-tailed prairie dog as threatened is warranted. However, because other species in greater need of protection also await listing, the FWS decided against listing the species then. In making this decision, the FWS suggested that delaying the listing would give individual states an opportunity to implement their own protection programs (Gerhardt 2000, Hughes 2000). Indeed, after the petition and initial finding but before the FWS's final finding, nine states moved toward cooperative plans that might afford protection to the species (Gerhardt 2000, Hughes 2000). Additionally, each state within the historic range is conducting a census of prairie dog populations and habitat (Robert Luce [Black-tailed Prairie Dog Conservation Team, Cheyenne, Wyoming], personal communication, January 2001).

Preserving threatened and endangered species is one element of environmental protection. Citizens of the United States favor environmental protection, especially when it positively affects their quality of life (Shindler et al. 1993). Moreover, research has shown that they believe government should do more about environmental protection either through stricter regulations or stronger enforcement of existing environmental laws, and that having more information does affect their voting decisions (Shindler et al. 1996, Pew 1997, Greenberg Quinlan Research 2000). These findings are important for wildlife managers engaged in prairie dog conservation: They need to know whether citizens believe that prairie dog issues affect their quality of life and whether cit- izens think the government should be taking action. Moreover, it is important to know which segments of the population view those concerns as important. People seem to want and use information about the environment and natural resources, and wildlife managers need to design programs to explain the connection between protecting a threatened species and people's daily lives.

Wildlife managers need answers to several questions to effectively implement federal or state programs. Among these questions are the following:

- What are the attitudes toward prairie dogs held by ranchers and farmers, environmentalists, and residents of urban and rural areas?

- What is the level of public knowledge about prairie dogs?

- How do attitude and knowledge vary among these groups?

- What are the sources of information on which the different groups rely?

Once managers have the answers, they can identify gaps in the public's understanding and design programs with a higher probability of success.

Wildlife management research has not traditionally focused on assessing citizen attitudes and knowledge (Kellert 1985, Reading 1993). However, over the past two decades more holistic attempts have been made to assess wildlife issues by 
surveying public attitudes. The results have provided managers, hunters, landowners, and environmentalists with an improved framework for expediting the policy process and rendering it more effective (Kellert and Clark 1991). At the same time, information about citizen knowledge has become more available. Despite the increasing use of this type of information in wildlife management, minimal data are available with respect to the public's attitude toward or knowledge of prairie dogs.

\section{Attitudes toward and perceptions of prairie dogs}

Surveys have demonstrated that with the exception of those who identify themselves as environmentalists, most people who live in states within the historic prairie dog range display little concern for the animals (Reading 1993, Dolan 1999). Overall, respondents who are more likely to care about prairie dogs tend to be younger, better educated, professional, and female; people employed in agricultural or natural resource extractive industries tend to be less concerned about the animals (Reading 1993, Lamb et al. 2001). However, researchers have found several dimensions of attitudes and perceptions.

Ranchers and farmers. Western ranchers generally dislike prairie dogs; they regard them as grass-eating pests that compete with cattle for food and as animals of little ecological value or ethical concern (O'Meilia et al. 1982, Reading 1993). The results of Reading's (1993) study demonstrated that 91 percent of ranchers surveyed in two counties of Montana believed they should not have to accept losses due to prairie dogs on public lands, and 97 percent favored controlling prairie dog numbers (Reading 1993). Ranchers claim that these losses stem from livestock stepping into prairie dog burrows and breaking legs and the destruction of grass and other vegetation, through which the prairie dogs reduce the number of livestock able to graze on a given section of land (64 Federal Register 57). Farmers who responded to studies or commented on plans complained about crop loss, damage to haying equipment, and draining of irrigated fields, all of which have been attributed to prairie dog activities (Hygnstrom and Virchow 1994, Long 1998).

Overall, most ranchers and farmers are concerned more about adequate prairie dog control than about the prairie dogs themselves (Reading 1993, Kayser 1998, Reading et al. 1999). Any negative attitudes they express appear to stem from restrictions on ranching operations and loss of control over management of public land (Reading 1993). However, Reading (1993) found a small number of ranchers with more positive regard for the animals, who favored maintaining a moderate prairie dog population on public grazing lands. The Wyoming Agricultural Statistics Service found in its survey of 1113 agricultural operators that younger respondents were more inclined than older ones to support conservation of prairie dogs and to favor a program that provided financial compensation for allowing prairie dogs to occupy their land. The same survey found that respondents with large acreage
(15,000 acres or more) showed the most interest (40 percent) in participating in a compensation program.

Rural and urban residents. The attitudes of rural and urban residents differ substantially with respect to the ecological value of the species. Rural residents are generally more negative toward prairie dogs than their urban counterparts, who tend to enjoy watching the animals (Reading 1993, Zinn and Andelt 1999). According to Reading (1993), the attitudes of residents of Billings, Montana, differed significantly from those of residents in nearby Phillips County, a rural region. In Billings, respondents expressed greater concern for the protection, recreational value, and ecological worth of prairie dogs. Residents of Phillips County expressed little to no concern for the protection of prairie dogs and reported perceiving no ecological and ethical value in them (Reading 1993, Reading et al. 1999). Reading (1993) explained that he found urban-rural residency and livestock dependence to be the most important indicators of support or antagonism toward prairie dogs. In their study of 646 residents of Fort Collins, Colorado, Zinn and Andelt (1999) reported a similar urban-rural pattern. Lamb and colleagues (2001) reported, following a study of more than 1900 respondents in 11 states, that urban respondents across the short-grass prairie region of the United States tended to be more protective of prairie dogs than rural respondents and attached a higher priority to protecting them.

Although rural and urban residents have different attitudes toward prairie dogs, the two groups do share a few perceptions (Reading et al. 1999, Zinn and Andelt 1999). According to John Sidle, an endangered species coordinator for the US Forest Service, both urban and rural residents perceive prairie dogs to be abundant (Long 1998). Furthermore, both groups perceive the animals as destructive toward vegetation (natural and ornamental) and generally favor controlling prairie dog populations (Reading 1993, Zinn and Andelt 1999).

Hunters are a group that cuts across the urban-rural divide. Although hunters opposed species reintroduction, they valued animals such as prairie dogs more than nonhunters did. This was particularly evident within rural populations, where rural hunters tended to have a more positive attitude toward prairie dogs and prairie dog management than did rural nonhunters (Reading 1993, Long 1998). Hunters' desire to see the prairie dog species maintained may be connected to both altruism and utilitarianism. Rural public attitudes usually support management of prairie dog colonies in coordination with other uses, such as ranching, hunting, and prairie dog watching (Reading 1993, Zinn and Andelt 1999).

Environmentalists. In contrast to many western ranchers and even the general public, those who identify themselves as environmentalists seem to stress the benefits of prairie dog communities. People who belong to conservation organizations reported a much more positive attitude toward prairie dogs than did other respondents in the studies we re- 
viewed. Those positive attitudes were primarily associated with the moral, ethical, and ecological arguments for maintaining prairie dogs (Reading et al. 1999). Environmentalists saw prairie dogs as a keystone species that regulates the prairie ecosystem by influencing primary production and increasing the diversity of plant and animal communities (Reading 1993, Kotliar et al. 1999, Reading et al. 1999).

Native Americans. On many Native American reservations, ranchers typically regard prairie dogs as "the scourge of the Earth" (Long 1998). This attitude derives from cultural, historical, and economic considerations. Prairie dog shooting programs bring money to reservations in the form of license and guide fees (Long 1998). However, this attitude is changing on a number of reservations. Some tribal leaders, such as those at the Fort Belknap reservation in Montana and the Rosebud Sioux reservation in South Dakota, have limited the number of licenses sold and attempted to remind the local communities that their ancestors once valued all the creatures of the prairie (Dolan 1999). Other Native American communities, such as the Cheyenne River Sioux in South Dakota, have developed holistic prairie management programs reflecting the interrelationship among and importance of all animals of the prairie (Roemer and Forrest 1996).

\section{Knowledge of prairie dogs}

Zinn and Andelt (1999) and Lamb and colleagues (2001) reported that negative attitudes toward prairie dogs were associated with familiarity and knowledge of the animals. As noted by Kellert (1993, p. 7), "Greater knowledge is often more a basis for reinforcing and rationalizing attitudes than a cause for attitudinal convergence or change. Despite this qualification, one may assume knowledge exerts a moderately important influence on attitudes toward wildlife." US citizens' knowledge of the environment is relatively sparse (Pierce and Lovrich 1986). Kellert (1993) found their knowledge about wildlife in particular to be limited. For example, only 40 percent of survey respondents knew that iguanas are not mammals. US citizens understood that habitat loss is an important cause of species decline, but they tended to overestimate the role of chemical and industrial pollution as a cause of species endangerment (Kellert 1993). With this in mind, it is important to look at what recent literature shows about people's knowledge of prairie dogs.

Ranchers and farmers. According to Reading (1993), ranchers in Phillips County, Montana, perceived themselves as having "great" knowledge of prairie dogs ( 88 percent said they "know a lot"). This perception was not substantiated by the results of Reading's (1993) study measuring the ranchers' actual level of prairie dog knowledge. Ranchers were found to have about the same level of knowledge about prairie dogs as some other groups in the study (Reading 1993). Sexton and colleagues (2001) reported in a study of respondents from the short-grass prairie region of the United States that rural respondents possessed higher levels of factual knowledge about prairie dogs, although urban residents reported knowing more terms related to the management of prairie dogs.

Reading (1993) found that farmers and ranchers reported personal experience as the most common source of their information ( 85 percent) about prairie dogs, with books, articles, and newspapers as other important sources. Somewhat fewer ranchers and farmers said they obtain information from friends, television, and literature provided by the Bureau of Land Management (Reading 1993). Oskam (1995) found that farmers preferred to rely on magazines as the primary source of information about agricultural practices, and in a much earlier study, Guither (1962) found that they relied on magazines, in addition to friends and neighbors, for information about farm practices. The magazines most commonly named by respondents to the Guither (1962) study were those devoted to practical farming information. Reading (1993) suggested that because a high level of perceived knowledge is associated with personal experience, attempts by managers to communicate simply by distributing new scientific findings might not be effective.

\section{General public}

Having asked respondents to indicate how much they knew about prairie dogs, Reading (1993) found that the general public's self-evaluation of knowledge was low. The US Geological Survey study reported that approximately half the respondents were able to correctly answer questions about how humans interact with prairie dogs; however, the vast majority could not correctly answer questions concerning specifics of prairie dog life history (Lamb et al. 2001, Sexton et al. 2001). On the basis of these data, the researchers suggested that "people may know something about general ecology, but when it comes to specifics about prairie dogs, knowledge is not high" (Lamb et al. 2001, p. 16). Finally, people who live directly beside prairie dog colonies possess more knowledge than other members of the general public (Zinn and Andelt 1999). The Fort Collins study showed that the level of knowledge dropped dramatically when residents lived even one house away from colonies (Zinn and Andelt 1999).

Both Zinn and Andelt (1999) and Lamb and colleagues (2001) reported that people with direct experience with prairie dogs — generally gained by being located near themare measurably more knowledgeable about and less inclined to accept risk associated with the animals. People living very near prairie dog colonies were more likely than other members of the public to report problems with the animals and were more concerned about the adverse effects of prairie dogs (Zinn and Andelt 1999). This concern might be classified as a quality-of-life environmental issue because the animals have a direct effect on people's lives. Fort Collins citizens who live very near prairie dogs would be more willing than the general public to accept poisoning as a control measure; the general public reported a preference for capture and relocation (Zinn and Andelt 1999). Of respondents who lived near colonies, those with the longest term of residence saw the animals in a more adverse light and were more will- 
ing to accept control by poisoning than were those with a shorter term of residence (Zinn and Andelt 1999). A large majority of all respondents in the Fort Collins study reported support for environmental protection. But as is the case with other quality-of-life environmental concerns-clean air and clean water, for example-respondents with the most knowledge reported a preference for protection from risk of adverse effects.

As important as understanding what people know is being aware of where they get their information. Respondents reported learning some or a great deal from personal experience ( 43 percent) and from friends and neighbors ( 27 percent). Only about a quarter of the respondents in the 11-state study said they had learned some or a great deal about prairie dogs from newspapers, television, or other media sources (Sexton et al. 2001).

\section{Implications for public policy}

To mitigate complaints from ranchers, farmers, and the resource extraction industry, many states have traditionally classified the prairie dog as a pest species and have allowed or encouraged ranchers and farmers to "take" (kill) prairie dogs (Roemer and Forrest 1996). Indeed, the actions of many government agencies have supported the attitudes and beliefs of farmers and ranchers.

Although the US Fish and Wildlife Service has not proposed listing the prairie dog as a threatened species, its determination in 2000 that the animal warranted federal listing has drawn increased attention to the debate over prairie dog management. A necessary first step in developing and implementing successful prairie dog management programs is understanding public attitudes toward and knowledge of the species and management options. The literature we have reviewed comes to a number of policy-relevant conclusions about public attitudes and knowledge:

- "Protection of prairie dogs does not evoke images of environmental protection, suggesting that the idea of these burrowing rodents as keystone species has not taken root in the perceptions of the general public" (Lamb et al. 2001).

- There is a divide between urban and rural attitudes. However, this characteristic does not explain the amount of knowledge people have. Although urban residents are relatively supportive of prairie dogs, ranchers and rural dwellers-especially those who have direct experience with the animals - are not.

- Research has shown one group-those with experience- to have greater knowledge than the general public (Jacobson and Marynowski 1997, Zinn and Andelt 1999). Thus, direct experience is important because it is connected with increased knowledge; however, it is also associated with negative attitudes toward prairie dogs (Lamb et al. 2001).

Another issue, beyond knowledge and attitude, concerns improved collaborative decision processes. One of the most noticeable trends in natural resource management over the past decade has been the emphasis on collaborative decisionmaking (Johnson 1999, Smith et al. 1999). The public has demanded, Congress has required, and resource managers have implemented a wide variety of planning and management processes that fully involve the public in deciding how wildlife and other natural resources are to be managed (Brown and Harris 2000). Citizen knowledge of prairie dog ecology and management may enable more effective participation in these collaborative processes.

\section{Principal questions that remain unanswered}

Steel et al. (1990) found that US citizens who are generally well educated are more likely than the general public to assign high estimates of risk to environmental issues. Their study also revealed that citizens with high levels of policy-relevant knowledge are less likely to perceive risks, thus showing a stronger correlation between value orientation and environmental risk perception than value orientation and policy-relevant knowledge. Similarly, Klineberg and colleagues (1998) found a correlation between higher education and greater environmental concern. Zinn and Andelt (1999) demonstrated that in one city the effects of prairie dogs on quality of life were related to knowledge and perceptions of risk. Finally, analysts at Greenberg Quinlin Research (2000) found that environmental issues with the greatest importance to the public are those that most affect perceptions of the quality of life. Although these studies add to our understanding of citizens' valuation of environmental issues such as prairie dogs, none of the ones we reviewed examined perceptions of prairie dogs over time, or in relation to characteristics such as the relative economic status of the communities. They generally failed to demonstrate how prairie dogs are related to other environmental amenities and affect people's quality of life. Questions remain concerning interconnections among environmental values, policy-relevant knowledge, demographic characteristics, preference for management options, and quality of life (e.g., risk of adverse effects).

Perception of risk seems to be an important factor in predicting orientation toward prairie dogs and prairie dog management. This explains why ranchers, farmers, rural residents, and people living near colonies know more (or believe they know more) but care less about protection of the animals. It would be worthwhile to investigate the relative nature of risk perception involving prairie dogs. Are prairie dogs relatively more or less threatening than other environmental risks? Is comparative risk a factor in shaping perception and attitude? Does evaluation of risk change with knowledge? How would a change in knowledge or risk perception affect the likelihood of a change in value orientation or attitude? What is most important in shaping preferences for prairie dog management: perception of risk, values, or knowledge?

Is it even possible to change the level of public knowledge about a species such as prairie dogs? And is it possible to help people understand where their knowledge of prairie dogs may be incomplete? To understand whether or not it is pos- 
sible to alter peoples' knowledge of prairie dogs, it is important to know the sources of information they trust and rely upon. The studies that have been conducted to date suggest an answer to this question. But the data from these studies are limited; there is a need for more extensive research to identify sources of knowledge about habitat management. Moreover, the literature we reviewed did not address the question of whether or how attitudes might change if the general public's level of knowledge rises.

The literature we reviewed was fairly conclusive in showing that environmentalists and many urban residents are relatively supportive of prairie dogs, although ranchers and rural dwellers are not. The literature also suggests that there may be a gap between perceived and actual knowledge about the species. Researchers believe that while increased knowledge does not necessarily lead to changes in attitude, it can lead to improved decisionmaking skills or more effective public involvement (Kellert 1993). Under what circumstances would increased knowledge lead to a better understanding of other groups' point of view? Would better understanding increase the likelihood of successful collaborative decisions?

Another set of unanswered questions relates to the attitudes and knowledge of government officials, including county, state, tribal, and federal wildlife and land management agencies. The level of knowledge about and attitude toward prairie dogs and prairie dog management among these officials have not been reported in the literature. Although there has been some discussion of public reliance on government reports or personal contacts with government officials for information on endangered species, we could find no studies that analyzed either the knowledge of such officials or the connection between their attitudes and knowledge and those of the local communities where they serve.

There are a number of overlapping agencies involved in the management of prairie dogs. In some cases the agencies classify prairie dogs in different ways, creating conflicting management goals. Is it possible to more effectively coordinate the management goals and policies among governmental agencies? Within the constraints of our federal system of government, what are the strategies most likely to result in coordination? An examination of the institutional obstacles and opportunities for prairie dog protection is needed. Such an analysis would be instructive for the management of other threatened but geographically widespread species. A few studies have created models for managing efficient spatial arrangements for prairie dogs and prioritizing areas in which to seek conservation easements for the protection and restoration of the prairie dog ecosystem (Proctor et al. 1998, Hof et al. 2002). These studies attempted to work through some existing institutional obstacles in order to optimize methods of prairie dog conservation. Although this type of research is extremely valuable, implementation will require a more complete understanding of existing institutional obstacles and opportunities.

Working toward any level of prairie dog management or conservation presents a demanding challenge, in part be- cause there are still numerous areas that need further study (box 1). Effective action requires understanding not only the biological phenomenon involved but the social and political aspects of the situation as well. The increasing emphasis on public relations and education in conservation programs in recent years is insufficient (Reading 1993, Reading et al. 1999). A substantial and interdisciplinary response is required. The values and attitudes people hold toward wildlife, how those values and attitudes are formed, and what levels of knowledge exist are all crucial issues for the ultimate success of prairie dog studies and conservation programs.

\section{Box 1. Future research needs}

Studies over time that show interconnections among environmental values, policy-relevant knowledge, quality-of-life issues, demographic characteristics, and preference for management options

Investigations of the relative nature of risk perception involving prairie dogs

Survey of information sources the public trusts and relies upon

Studies that are geographically more expansive

Investigation of how attitudes may change if public knowledge increases

Survey of government officials' attitudes and knowledge of prairie dogs

Analysis of institutional obstacles and opportunities

\section{Acknowledgments}

We wish to acknowledge the helpful assistance of Ayeisha Brinson and Natalie Sexton in the preparation of this article and that of Dale Crawford, who worked on graphics. We are very grateful for the suggestions provided by Dean Biggins, Nicholas P. Lovrich, Leah Wilds Magennis, and Dennis L. Soden, who served as part of the internal approval process for our manuscript, as well as for the comments and suggestions of three anonymous reviewers.

\section{References cited}

Barnes, AM. 1993. A review of plague and its relevance to prairie dog populations and the black-footed ferret. Pages 28-37 in Oldemeyer JT, Biggins DE, Miller BJ, Crete R, eds. Management of Prairie Dog Complexes for Reintroduction of the Black-footed Ferret. Washington (DC): US Fish and Wildlife Service. Biological Report 13.

Brown G, Harris CC. 2000. The US Forest Service: Whither the new resource management paradigm? Journal of Environmental Management 58: $1-19$.

Collins AR, Workman JP, Uresk DW. 1984. An economic analysis of blacktailed prairie dog (Cynomys ludovicianus) control. Journal of Range Management 37: 358-361.

Dolan CC. 1999. The national grasslands and disappearing biodiversity: Can the prairie dog save us from an ecological desert? Environmental Law 29: 213-234.

Dunlap TR. 1988. Saving America's Wildlife. Princeton (NJ): Princeton University Press. 
Gerhardt G. 2000. "Endangered” prairie dogs on hold. Denver Rocky Mountain News, 4 February.

Greenberg Quinlan Research. 2000. Environment top tier voting issue. (11 June 2002; www.voteenvironment.org/media_pr.html)

Guither HD. 1962. Characteristics, motivations, and adjustment problems of farmers who leave farming. PhD dissertation. Department of Agricultural Economics, University of Illinois, Urbana-Champaign.

Hof J, Beavers M, Uresk DW, Schenbeck GL. 2002. Optimizing habitat location for black-tailed prairie dogs in southwestern South Dakota. Ecological Modelling 147: 11-21.

Hughes J. 2000. Prairie dog gets a boost. Denver Post Online. (11 June 2002; www.denverpost.com/news)

Hygnstrom SE, Virchow DR. 1994. Prairie dogs. Pages B85-B96 in Hygnstrom S, Timm R, Larson G, eds. Prevention Control and Wildlife Damage. Lincoln: University of Nebraska.

Jacobson SK, Marynowski SB. 1997. Public attitudes and knowledge about ecosystem management on Department of Defense land in Florida. Conservation Biology 11: 770-781.

Johnson TR. 1999. Community-based forest management in the Philippines. Journal of Forestry 97: 26-30.

Kayser M. 1998. Have varmint rifle, will travel. American Hunter (June): 44-47, 61-62.

Kellert SR. 1985. Social and perceptual factors in endangered species management. Journal of Wildlife Management 49: 528-536.

. 1993. Attitudes, knowledge, and behavior toward wildlife among the industrial superpowers: United States, Japan, and Germany. Journal of Social Issues 49: 53-69.

Kellert SR, Clark TW. 1991. The theory and application of a wildlife policy framework. Pages 17-36 in Mangun WR, Nagel SS, eds. Public Policy and Wildlife Conservation. New York: Greenwood Press.

Klineberg SL, McKeever M, Rothenbach B. 1998. Demographic predictors of environmental concern: It does make a difference how it's measured. Social Science Quarterly 79: 734-753.

Knopf FL. 1993. Avian assemblages on altered grasslands. Studies in Avian Biology 15: 247-257.

Kotliar NB, Baker BW, Whicker AD, Plumb G. 1999. A critical review of assumptions about the prairie dog as a keystone species. Environmental Management 24: 177-192.

Lamb BL, Cline K, Brinson A, Sexton N, Ponds PD. 2001. Citizen Knowledge of and Attitudes toward Black-tailed Prairie Dogs: Completion Report. Fort Collins (CO): US Geological Survey. Open-File Report 01-471.

Long ME. 1998. The vanishing prairie dog. National Geographic 193: $116-130$.

Miller BJ, Reading RP, Forest S. 1996. Prairie Night: Black-Footed Ferrets and the Recovery of Endangered Species. Washington (DC): Smithsonian Press.

Mulhern D, Knowles CJ. 1995. Black-tailed prairie dog status and future conservation planning. Pages 19-29 in Uresk D, Schenbeck GL, O’Rourke JT, eds. Conserving Biodiversity on Native Rangelands. Fort Collins (CO): USDA Forest Service. General Technical Report RM-GTR-298.
New Mexico Black-tailed Prairie Dog Working Group. 2001. Conservation and Management Strategic Plan for Black-Tailed Prairie Dogs in New Mexico. 15 November.

O’Meilia ME, Knopf FL, Lewis JC. 1982. Some consequences of competition between prairie dogs and beef cattle. Journal of Range Management 35: 580-585.

Oskam JB. 1995. Diffusion of agricultural health and safety information: A two-part study of Oklahoma farmers and extension agricultural engineers. Journal of Applied Communications 7: 13-25.

[Pew] Pew Research Center for the People and the Press. 1997. November 1997 news interest index. (11 June 2002; http//people-press.org/)

Pierce JC, Lovrich NP Jr. 1986. Water Resources, Democracy, and the Technical Information Quandary. Millwood (NY): Associated Faculty Press.

Proctor J, Beltz M, Haskins W. 1998. A GIS model for identifying potential black-tailed prairie dog habitat in the northern Great Plains shortgrass prairie. (11 June 2002; www.esri.com/library/)

Reading R. 1993. Toward an endangered species reintroduction paradigm: A case study of the Black-footed ferret. PhD dissertation. Yale University, New Haven, CT.

Reading RP, Miller BJ, Kellert SR. 1999. Values and attitudes toward prairie dogs. Anthrozos 12: 43-52.

Roemer DM, Forrest SC. 1996. Prairie dog poisoning in northern Great Plains: An analysis of programs and policies. Environmental Management 20: 349-359.

Sexton NR, Brinson A, Ponds PD, Cline K. 2001. Citizen Knowledge and Perception of Black-tailed Prairie Dog Management: Report to Respondents. Fort Collins (CO): US Geological Survey. Open-File Report 01-467.

Shindler B, List PL, Steel B. 1993. Managing federal forests: Public attitudes in Oregon and nationwide. Journal of Forestry 9: 36-42.

Shindler B, Steel B, List PL. 1996. Public judgments of adaptive management: A response from forest communities. Journal of Forestry 94: 4-12.

Smith PD, McDonough MH, Mang MT. 1999. Ecosystem management and public participation: Lessons from the field. Journal of Forestry 97: $32-38$.

Stapp P. 1998. A reevaluation of the role of prairie dogs in Great Plains grasslands. Conservation Biology 12: 1253-1259.

Steel B, Soden DL, Warner RL. 1990. The impact of knowledge and values on perceptions of environmental risk to the Great Lakes. Society and Natural Resources 3: 331-348.

Uresk D, Paulson DB. 1989. Estimated carrying capacity for cattle competing with prairie dogs and forage utilization in western South Dakota. Pages 287-290 in Szaro RC, Severson KE, Patton DR, eds. Symposium on Management of Amphibians, Reptiles, and Small Mammals in North America, 19-21 July 1988. Washington (DC): US Forest Service. US Forest Service General Technical Report RM-166.

Zinn H, Andelt W. 1999. Attitudes of Fort Collins, Colorado residents toward prairie dogs. Wildlife Society Bulletin 27: 1098-1106. 